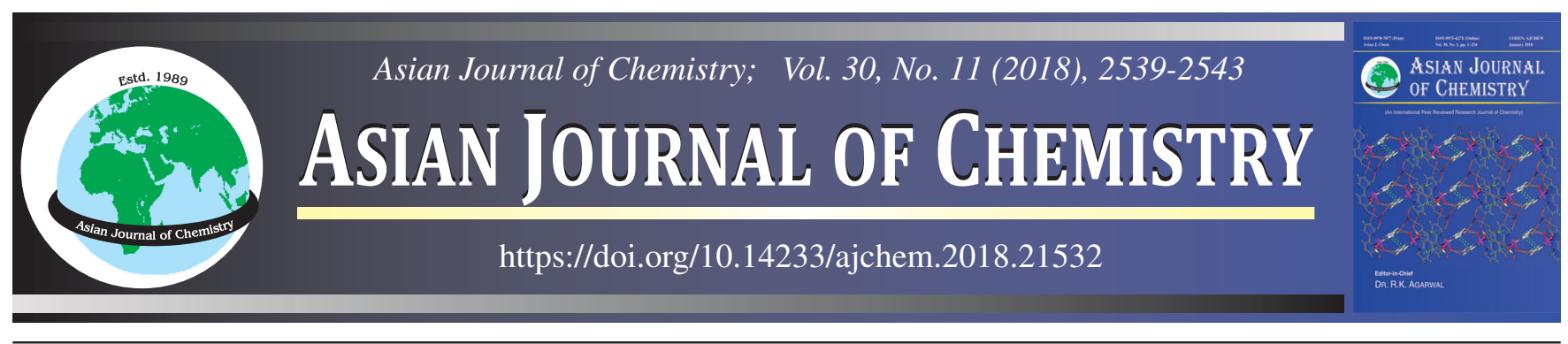

\title{
Interaction of Cephalexin Monohydrate and Diclofenac Sodium with Human Erythrocyte Membrane: Adsorption Study and Equilibrium Isotherm Analysis
}

\author{
Saja S. Al-Taweel ${ }^{1, *}$, SAAdoOn A. Isa $^{2}$ and Ramzi R. Al-Ani ${ }^{3}$
}

${ }^{1}$ Department of Chemistry, College of Science, University of Al-Qadisiyah, Al-Diwaniyah, Qadisiyyah Province, Iraq

${ }^{2}$ Al-Hikma Foundation, Canada

${ }^{3}$ Department of Chemistry, College of Science, University of Al-Mustansiriyah, Baghdad, Iraq

*Corresponding author: E-mail: saja.Al-Taweel@ qu.edu.iq

Received: 19 June 2018;

Accepted: 10 August 2018;

Published online: 27 September 2018;

AJC-19108

To elucidate the mechanism of interaction of biological surfaces with drugs, in vitro study of interaction of erythrocyte membrane from healthy individuals with two type of drugs was performed at $37.5^{\circ} \mathrm{C}$ and at physiological $\mathrm{pH}$ 7.4. Cephalexin monohydrate and diclofenac sodium were chosen for this purpose. The blood samples were collected from healthy volunteers ( 21 males and 19 females), aged 20 to 40 years (mean age $28 \pm 6$ years). Hypotonic solution was used to isolate the erythrocyte membrane from red blood cells. The amount of cephalexin $\cdot \mathrm{H}_{2} \mathrm{O}$ or diclofenac sodium binding to erythrocyte membrane was significantly increased $(\mathrm{p}<0.01)$ with increasing drug concentration and there was no significant difference $(\mathrm{p}>0.05)$ in amount of drugs uptake by erythrocyte membrane of male or female. There was no significant difference $(\mathrm{p}>0.05)$ between the amount of cephalexin $\cdot \mathrm{H}_{2} \mathrm{O}$ binding to erythrocyte membrane and that for diclofenac sodium. The results indicated the applicability of Langmuir and Freundlich isotherms of drugs binding to erythrocyte membrane. The models that fit the experimental data assume the presence of multiple binding sites on the surface of erythrocyte membrane. The binding data and Scatchard plot suggested the existence of non-identical independent sites, in human erythrocyte membrane, interacting with cephalexin $\cdot \mathrm{H}_{2} \mathrm{O}$ and having different affinities.

| Keywords: Erythrocyte membrane, Interaction, Cephalexin monohydrate, Diclofenac sodium, Adsorption Isotherms.

\section{INTRODUCTION}

Erythrocyte membrane, like all other eukaryotic plasma membranes, is composed of a bilayer of several different classes of lipid along with a variety of protein molecules [1]. It contains $52 \%$ proteins, $40 \%$ lipids and $8 \%$ carbohydrates that is bound to lipids (glycolipids) or proteins (glycoproteins) [2]. The lipids form a rather continuous bilayer in which the outer layer contains mainly phosphatidylcholine and sphingomyelin, and the inner one, phosphatidylethanolamine and phosphatidylserine. Lipids provide mechanical stability and a strong tendency to form closed structures [3]. Membrane proteins are classified as peripheral or integral. Peripheral proteins are molecules that are bound to membrane primarily through interactions with integral membrane proteins. The integral proteins represent more than $70 \%$ of membrane proteins and are very firmly associated with the membrane, the two major integral proteins are band and glycophorin [4].The outer surface of erythrocyte membrane is negatively charged, due to presence of salicyclic acid residues as well as carboxyl and phosphate groups [5]. The presence of charges on the external surface of biological membranes influences to a remarkable degree their electrical behaviour and physico-chemical properties [6].Various materials have been shown to adsorb or interact with the erythrocyte membrane, such as adsorption of different amino acids (L-alanine, glycine, L-glutamine and L-leucine) [7], anti A or anti B-antibodies [8] and drugs $[9,10]$. The interaction of drugs with erythrocyte membrane may occurs through the electrostatic attraction with negatively charged lipids or with negatively charged proteins of membrane skeleton [1]. These interactions are supposed to be involved in the modulation of membrane fluidity as well as in the regulation of membrane-related processes [11].

Elferink [12] studied the binding of chlorpromazine $\cdot \mathrm{HCl}$ and its quaternary analogue chlorpromazine methoiodide to

This is an open access journal, and articles are distributed under the terms of the Creative Commons Attribution-NonCommercial 4.0 International (CC BY-NC 4.0) License, which allows others to copy and redistribute the material in any medium or format, remix, transform, and build upon the material, as long as appropriate credit is given and the new creations are licensed under the identical terms. 
open and resealed human erythrocyte ghost membranes. The results indicated that the quaternary compound is confined to the outside face of membrane. For both compounds two classes of binding sites are available. The strongest binding sites are mainly located on the inner surface of membrane. Numerous reports have demonstrated the nature of binding between certain agents and the receptor sites in red blood cell membrane. It has been suggested that binding of stilbendisulfonic acids to the protein in band 3 of red blood cell membrane occurs through the formation of covalent binding (irreversible binding) after initial rapid non-covalent binding [13]. On the other hand, it was found that the covalent bond formation between 1-fluoro-2,4dinitrobenzene and anion permeability-controlling sites on the protein in band 3 is direct and not preceded by a step that involves non-covalent binding [14]. It has long been known that certain drugs (like salicylic acid and its derivatives) interact with the protein in red cell membrane and act as a reversible and noncompetitive inhibitors of anion permeability. The inhibitory action of these drugs influence by many factors related to the structure of drug molecule, such as hydrophobicity of molecule, electron distribution within the molecule and steric effects [15].

The aim of the present work is to evaluate the interaction of cephalexin. $\mathrm{H}_{2} \mathrm{O}$ and diclofenac sodium with erythrocyte membrane. It is planned to carry out this part of research in vitro aiming to get some informations regarding the mechanism of interaction of this type of biological surfaces with the drugs (cephalexin monohydrate and diclofenac sodium) under study.

\section{EXPERIMENTAL}

Subjects: Fourty blood samples have been collected from healthy Iraqi volunteers ( 21 males and 19 females), aged 20 to 40 years (mean age $28 \pm 6$ years).

Preparation of erythrocyte membrane: Erythrocyte membranes were prepared according to Reinila et al. [16]. Fresh blood samples $(10 \mathrm{~mL})$ containing heparin as an anticoagulant were centrifuged at $3000 \mathrm{rpm}$. The erythrocytes were resuspended in ice-cold isotonic saline $(\mathrm{NaCl} 0.9 \%)$ and washed by three successive centrifugations ( $3000 \mathrm{rpm}$ ) for $5 \mathrm{~min}$. Packed RBCs $(3 \mathrm{~g})$ were transferred into $30 \mathrm{~mL}$ of hypotonic medium $(10 \mathrm{mM}$ tris-HCl, $\mathrm{pH} 7.4$, containing $0.1 \mathrm{mM}$ EGTA). The tubes were centrifuged at $4{ }^{\circ} \mathrm{C}$ for $20 \mathrm{~min}$ at $12000 \mathrm{rpm}$. After aspiration of supernatant, the cells were resuspended in hypotonic medium and treated as above. The final pellet of RBC membranes was resuspended in tris-EGTA buffer and stored at $20^{\circ} \mathrm{C}$ in deep frozen until assayed.

Adsorption on erythrocyte membrane: Solutions of each drug (cephalexin $\cdot \mathrm{H}_{2} \mathrm{O}$ or diclofenac sodium) of known concentrations $(0.2-5 \mathrm{mM})$ in buffer solution $(\mathrm{pH} 7.4)$ were added to flasks containing $0.2 \mathrm{~mL}(\sim 0.2 \mathrm{~g})$ of erythrocyte membrane suspension. The flasks were shaken in waterbath at $37.5^{\circ} \mathrm{C}$ for $45 \mathrm{~min}$. After the period of incubation, the suspensions were centrifuged at $4000 \mathrm{rpm}$ for $20 \mathrm{~min}$. The clear supernatants were assayed for drug, after appropriate dilution, using UVvisible spectrophotometer. The amount of drug adsorbed was calculated from the following equation:

$$
\mathrm{Q}_{\mathrm{e}}=\frac{\mathrm{V}\left(\mathrm{C}_{\mathrm{o}}-\mathrm{C}_{\mathrm{e}}\right)}{\mathrm{m}}
$$

where $\mathrm{Q}_{\mathrm{e}}$ is the quantity adsorbed, $\mathrm{m}$ is the weight of erythrocyte membrane $(\mathrm{g}), \mathrm{C}_{\mathrm{o}}$ is the initial concentration of drug $(\mathrm{mg} / \mathrm{L})$, $\mathrm{C}_{\mathrm{e}}$ is the equilibriumconcentration of drug $(\mathrm{mg} / \mathrm{L})$ and $\mathrm{V}$ is the volume of solution (L).

Protein content estimation: The protein content of erythrocyte membrane was estimated according to Lowery method [17] using bovine serum albumin as standard.

\section{RESULTS AND DISCUSSION}

The binding of cephalexin $\cdot \mathrm{H}_{2} \mathrm{O}$ and diclofenac sodium to erythrocyte membranes from healthy individuals at $37.5^{\circ} \mathrm{C}$ and $\mathrm{pH} 7.4$ was investigated. The results show a consistent and significant increase $(\mathrm{p}<0.01)$ in the amounts of drug uptake by erythrocyte membrane with increasing drug concentration. The binding of drugs to erythrocyte membrane for both sex was studied. No significant difference $(p>0.05)$ in amount of drug uptake by erythrocyte membrane of male or female was noticed (Table-1).

\section{TABLE-1}

AMOUNT OF DRUGS UPTAKE BY THE SURFACE OF ERYTHROCYTE MEMBRANE FOR MALE AND FEMALE EXPRESSED $(\mathrm{mg} / \mathrm{g})$

\begin{tabular}{cc|cc}
\hline \multicolumn{2}{c|}{ Cephalexin· $\mathrm{H}_{2} \mathrm{O}$} & \multicolumn{2}{c}{ Diclofenac sodium } \\
\hline Male* & \multicolumn{1}{c|}{ Female* } & Male* & Female* \\
\hline $0.76 \pm 0.28$ & $0.82 \pm 0.19$ & $0.54 \pm 0.26$ & $0.52 \pm 0.26$ \\
$1.66 \pm 0.48$ & $1.72 \pm 0.30$ & $1.04 \pm 0.26$ & $1.16 \pm 0.26$ \\
$3.85 \pm 0.49$ & $3.95 \pm 0.26$ & $3.21 \pm 0.39$ & $3.12 \pm 0.32$ \\
$5.30 \pm 0.58$ & $5.82 \pm 0.98$ & $6.76 \pm 0.61$ & $6.84 \pm 0.58$ \\
$9.78 \pm 0.74$ & $10.02 \pm 0.77$ & $7.88 \pm 0.80$ & $7.63 \pm 0.72$ \\
$10.83 \pm 0.95$ & $11.08 \pm 0.96$ & $8.24 \pm 1.22$ & $8.67 \pm 1.15$ \\
$11.77 \pm 0.85$ & $11.38 \pm 0.98$ & $9.31 \pm 0.94$ & $9.32 \pm 1.15$ \\
\hline
\end{tabular}

Fig. 1 shows the adsorption isotherms of cephalexin $\cdot \mathrm{H}_{2} \mathrm{O}$ and diclofenac sodium. The general shape of adsorption isotherm of cephalexin $\mathrm{H}_{2} \mathrm{O}$ have $\mathrm{L}_{4}$ type isotherm, while the adsorption isotherm of diclofenac sodium is $\mathrm{L}_{2}$ type feature of Giles classification [18].

The adsorption isotherm of cephalexin $\cdot \mathrm{H}_{2} \mathrm{O}$ by erythrocyte membrane (Fig. 1a) is not continuous, there is a major break (step) in which the amount of drug adsorbed appears to rise rapidly at a particular drug concentration. This result agrees with the report of Bikhazi et al. [19], who reported the adsorption isotherms of ouabain on hepatocytes from normal and diabetic rats are not continuous. They assumed the presence of multiple receptors on the cell surface and only when a specific fraction of total number of one receptor have effectively reacted will the other receptors initiate reaction with the ligand. They also suggested the existence of two receptors in normal and diabetic hepatocytes, interacting with ouabain and having different affinities for drug.

The experimental data were explained using the theoretical Langmuir equation and empirical Freundlich equation (eqns. 2 and 3 ).

$$
\frac{\mathrm{C}_{\mathrm{e}}}{\mathrm{Q}_{\mathrm{e}}}=\frac{1}{\mathrm{Q}_{\mathrm{m}} \mathrm{K}_{\mathrm{L}}}+\left(\frac{1}{\mathrm{Q}_{\mathrm{m}}}\right) \cdot \mathrm{C}_{\mathrm{e}}
$$



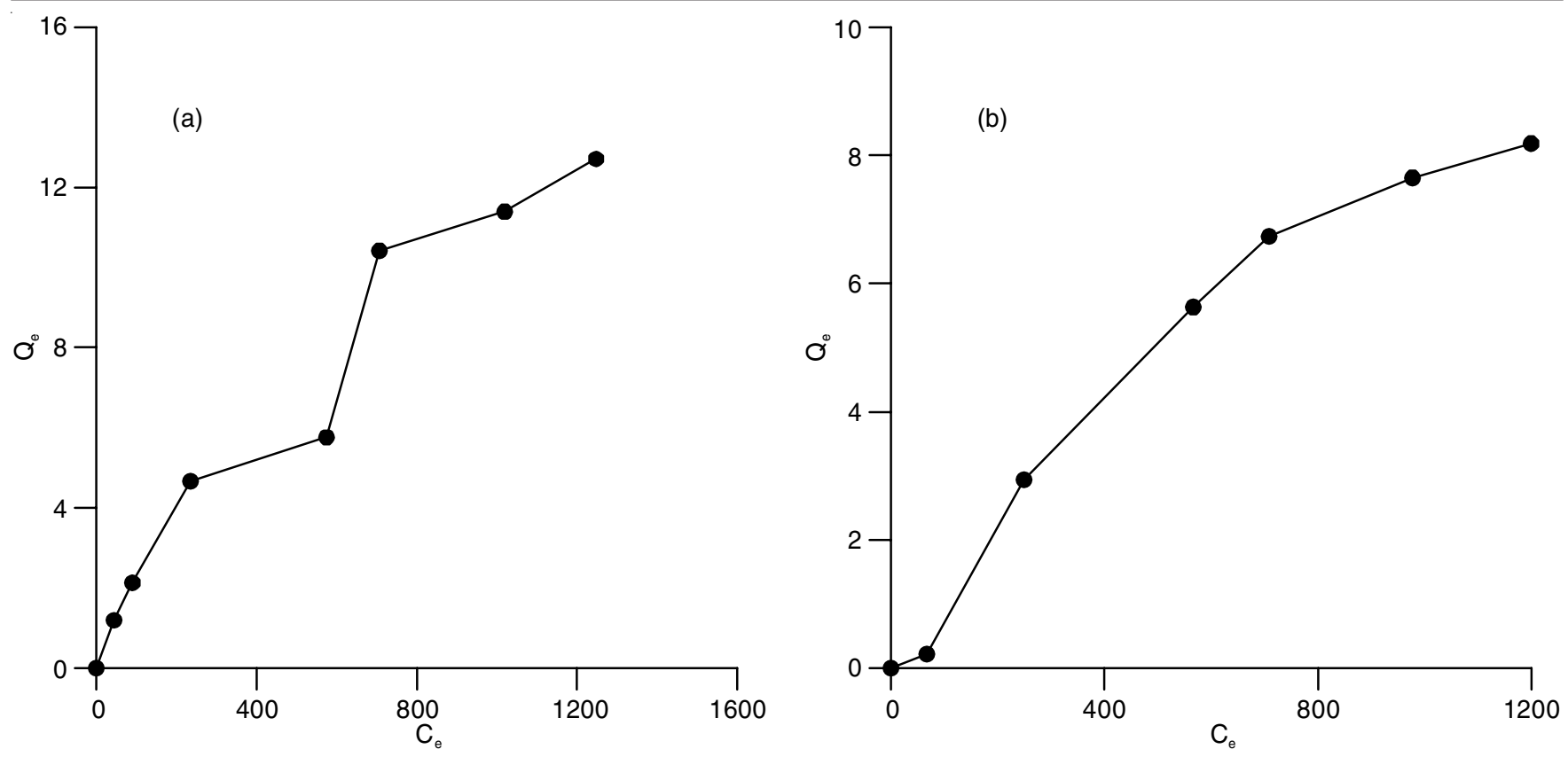

Fig. 1. Adsorption isotherms of (a) cephalexin $\cdot \mathrm{H}_{2} \mathrm{O}$, (b) diclofenac sodium,on erythrocyte membrane at $37.5{ }^{\circ} \mathrm{C}$

where $\mathrm{Q}_{\mathrm{e}}(\mathrm{mg} / \mathrm{g})$ is the quantity adsorbed per unit weight, $\mathrm{C}_{\mathrm{e}}$ $(\mathrm{mg} / \mathrm{L})$ is the equilibrium concentration, $\mathrm{Q}_{\mathrm{m}}(\mathrm{mg} / \mathrm{g})$ and $\mathrm{K}_{\mathrm{L}}$ $(\mathrm{L} / \mathrm{mg})$ are Langmuir isotherm constants.

$$
\log \mathrm{Q}_{\mathrm{e}}=\log \mathrm{K}_{\mathrm{f}}+\frac{1}{\mathrm{n}} \log \mathrm{C}_{\mathrm{e}}
$$

where $K_{f}$ and $n$ are Freundlich constants; $1 / n$ is a function of the strength of adsorption in adsorption process.

The results illustrated the applicability of Langmuir and Freundlich isotherms for both drugs as shown by the linear relationships of $\mathrm{C}_{\mathrm{e}} / \mathrm{Q}_{\mathrm{e}}$ versus $\mathrm{C}_{\mathrm{e}}$ (Fig. 2) and $\log \mathrm{Q}_{\mathrm{e}}$ versus $\log$ $\mathrm{C}_{\mathrm{e}}$ (Fig. 3).

A number of binding sites are involved in the binding of adsorbate molecules (called ligand) to macromolecules, and

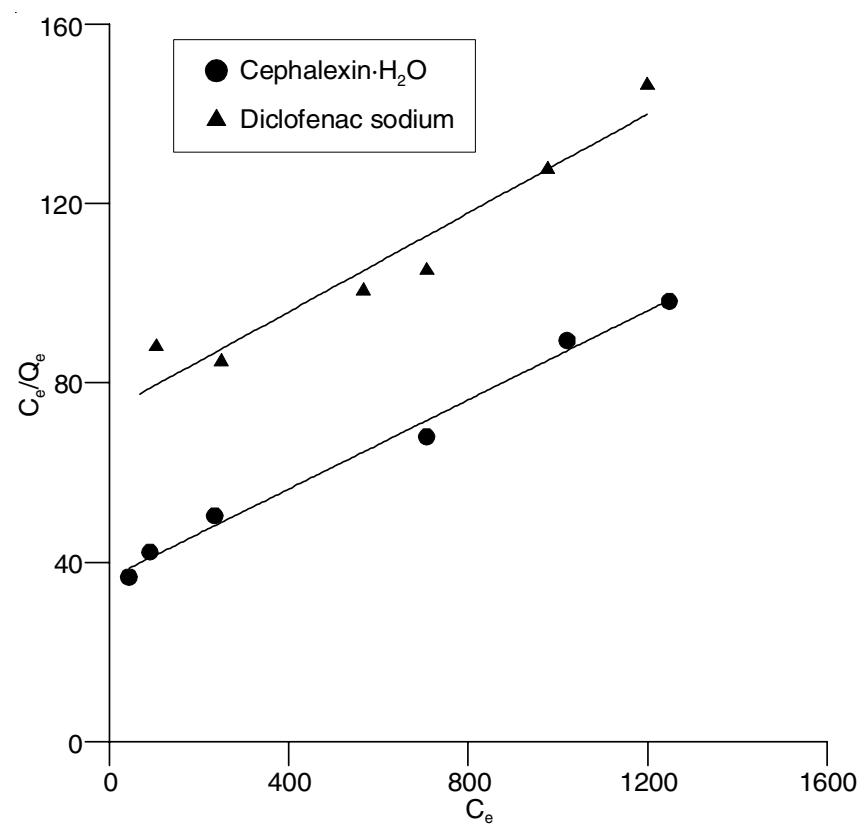

Fig. 2. Linear form of Langmuir isotherm of cephalexin $\cdot \mathrm{H}_{2} \mathrm{O}$ and diclofenac sodium on erythrocyte membrane

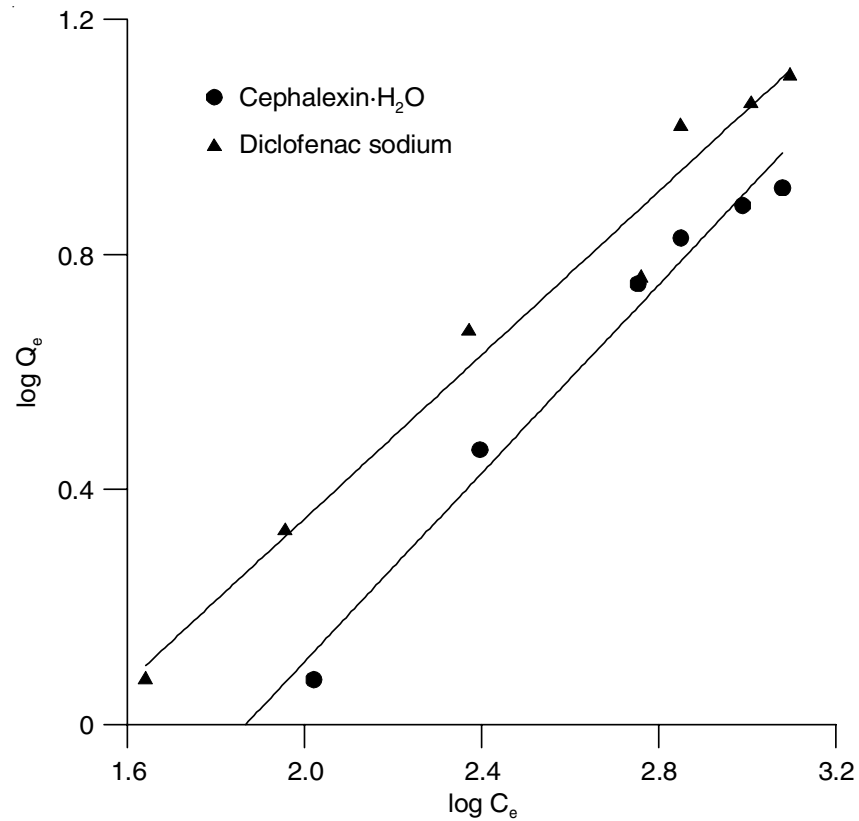

Fig. 3. Freundlich adsorption isotherms of cephalexin $\cdot \mathrm{H}_{2} \mathrm{O}$ and diclofenac sodium on erythrocyte membrane

sometimes they behave identically and act quite independently of each other. This is the simplest situation and such systems obey an equation of Langmuir form. However, in some important cases the occupation of one site affects the strength of binding at other sites; in other words, behaviour is favourable [20].

Most equations that describe the binding of adsorbate molecules to macromolecules are expressed in terms of dissociation constant $\left(\mathrm{k}_{\mathrm{d}}\right)$ and the number of moles of adsorbate molecule bound to one mole of macromolecules (r), therefore the Langmuir equation can be written in the following form [21]:

$$
\mathrm{r}=\frac{[\mathrm{A}]}{\mathrm{k}_{\mathrm{d}}+[\mathrm{A}]}
$$


where $[\mathrm{A}]$ represent the concentration of unbound ligand at equilibrium. This equation is usually rewritten in one of two forms that allow the data to be plotted on a straight line. One form is:

$$
\frac{\mathrm{r}}{[\mathrm{A}]}=\frac{1}{\mathrm{k}_{\mathrm{d}}}-\frac{\mathrm{r}}{\mathrm{k}_{\mathrm{d}}}
$$

in which a plot of $\mathrm{r} /[\mathrm{A}]$ versus $\mathrm{r}$ gives a straight line having a slope of $-1 / k_{d}$. If all binding sites are identical and independent, the relevant equations analogous to eqn. 5 as:

$$
\frac{\mathrm{r}}{[\mathrm{A}]}=\frac{\mathrm{n}}{\mathrm{k}_{\mathrm{d}}}-\frac{\mathrm{r}}{\mathrm{k}_{\mathrm{d}}}
$$

where $\mathrm{n}$ is the number of binding sites and $\mathrm{k}_{\mathrm{d}}$ is an average dissociation constant. With eqn 6 (often called Scatchard equation), a plot of $r /[\mathrm{A}]$ versus $r$ gives a line having a slope of $-1 / k_{d}$ and an $\mathrm{x}$-intercept of $\mathrm{n} / \mathrm{k}_{\mathrm{d}}$.

If the binding sites are not both identical and independent, neither of the plots, $1 / \mathrm{r}$ versus $1 /[\mathrm{A}]$ nor $\mathrm{r} /[\mathrm{A}]$ versus $\mathrm{r}$, will give straight lines. Eqn. 6 can be re-written in the form:

$$
\frac{\mathrm{Q}_{\mathrm{e}}}{\mathrm{C}_{\mathrm{e}}}=\frac{\mathrm{n}}{\mathrm{k}_{\mathrm{d}}}-\frac{\mathrm{Q}_{\mathrm{e}}}{\mathrm{k}_{\mathrm{d}}}
$$

The adsorption data and eqn. 7 were used to construct a Scatchard plots for binding of cephalexin $\cdot \mathrm{H}_{2} \mathrm{O}$ and diclofenac sodium to erythrocyte membrane, where $\mathrm{Q}_{\mathrm{e}} / \mathrm{C}_{\mathrm{e}}$ is plotted as a function of amount of drug uptake by membrane (Qe) (Fig.4).

As shown in Fig. 4, the Scatchard plots of adsorption data of both drugs are different. The Scatchard plot of cephalexin. $\mathrm{H}_{2} \mathrm{O}$ revealed the existence of two types of binding sites which are non-identical and independent. This result is in agreement with that reported by Ishida et al. [22] and Elferink [14].

Diclofenac sodium to erythrocyte membrane: There is an increasing evidence that erythrocyte membrane is asymmetric with regard to proteins as well as to phospholipids. In erythrocyte membrane the majority of aminophospholipids, phosphatidylserine and phosphatidylethanolamine, are located in the

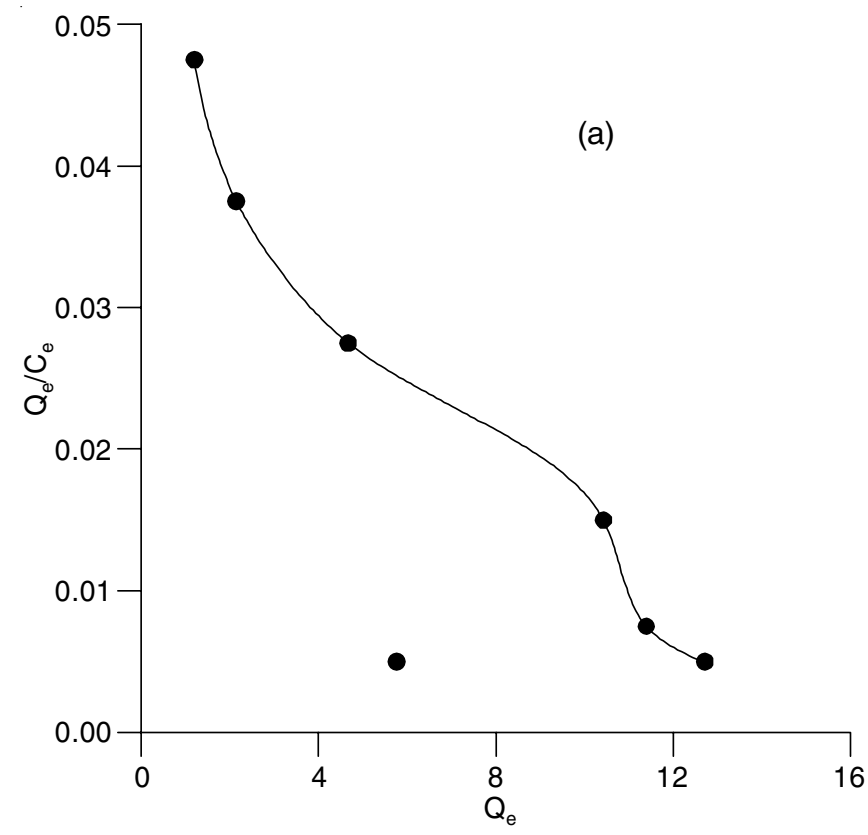

inner leaflet, whereas phosphatidylcholine and sphingomyelin, are localized predominantly in the outer leaflet of lipid bilayer [23]. Most proteins of erythrocyte membrane being located in the inner half of the membrane [24]. Sheetz and Singer [25] have proposed that two halves of an asymmetric membrane can respond differently to a perturbation and thus act as bilayer couples. They attributed the different effects of amphipatic drugs on erythrocyte morphology to a differential distribution of drugs in the erythrocyte membrane as a consequence of the presence of phosphatidylserine in the inner half of membrane.

The nature of interaction of cephalexin $\cdot \mathrm{H}_{2} \mathrm{O}$ with erythrocyte membrane may be related to the possibility of drug adsorption on both faces of membrane. Elferink [14] showed that chlorpromazine $\cdot \mathrm{HCl}$ was bound to both phases of membrane and the drug was preferentially bound to the inside face of membrane. He also found that the greater number of binding sites on the inside face is associated with the presence of phosphatidylserine in that side of the membrane and possibly with the presence of more protein binding sites on the inner half as compared to the outer half of membrane.

In erythrocytes, the inner layer of membrane is rich in phosphatidylserine - a lipid bearing net negative charge at neutral $\mathrm{pH}$. Negatively charged lipids are absent in the outer layer. On the other hand, cephalexin. $\mathrm{H}_{2} \mathrm{O}$ at neutral $\mathrm{pH}$ may occurs in protonated form [ $\mathrm{pk}_{\mathrm{a}}=2.7$ (4-carboxylic acid) and 6.96 (7/ $\alpha$-ammonium chain)]. Hendrich et al. [26] found that preferential binding of thioridazine (bears positive charge at neutral $\mathrm{pH}$ ) with the inner leaflet of membrane was due to the electrostatic attraction with negatively charge lipids as well as to its interaction with negatively charged proteins of membrane skeleton. It was suggested that phosphatidylserine in cytoplasmic half of the membrane could provide a negative field, attracting cationic drugs into cytoplasmic half [7]. The presence of charged groups at membrane surface will influence the distribution of mobile counter-ions. Surface of erythrocyte membrane normally carry net negative charge. This surface fixed charge leads to the formation of a diffuse electrical double layer in which the

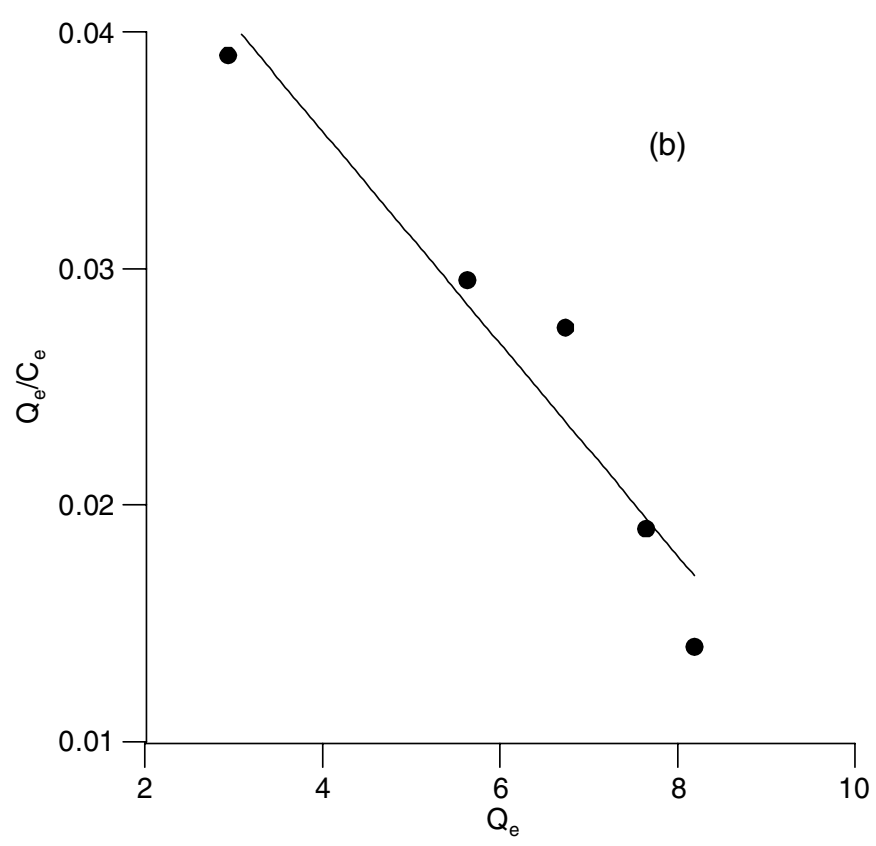

Fig. 4. Scatchard plots for the binding of (a) cephalexin $\cdot \mathrm{H}_{2} \mathrm{O}$, (b) diclofenac sodium to erythrocyte membrane 
charge at the surface is balanced by charges of opposite sign in the medium immediately adjacent to the surface [27]. Moreover, hydrophobic properties of drug molecule may play an important role in the nature of binding to erythrocyte membrane. The amount of diclofenac sodium adsorbed was non- significantly less $(\mathrm{p}>0.05)$ than the amount of cephalexin $\cdot \mathrm{H}_{2} \mathrm{O}$ uptake by erythrocyte membrane. There is no specific factor in the interpretation of this behaviour, but this may be attributed to the similarity in molecular weight of both drugs. Multiple factors can play a role in diclofenac sodium interaction with the membrane surface such as lipophilicity, stereochemistry and geometry of drug molecule, the distribution of charge on molecule and number of active functional groups in molecule bears. It is more likely the geometrical and electrostatic factors can affect diclofenac sodium bound to both sides of membrane surface.

\section{Conclusion}

The surface of human erythrocyte membrane consists of multiple binding sites with different affinities to interact with the drugs. The adsorption isotherm of cephalexin $\cdot \mathrm{H}_{2} \mathrm{O}$ by erythrocyte membrane is not continuous, there is a major break (step) in which the amount of drug adsorbed appears to rise rapidly at a particular drug concentration. There is no sex differences in the amounts of drugs binding to erythrocyte membrane. The amount of diclofenac sodium adsorbed was non-significantly less $(\mathrm{p}>0.05)$ than the amount of cephalexin $\cdot \mathrm{H}_{2} \mathrm{O}$ uptake by erythrocyte membrane. It is more likely that geometrical and electrostatic factors can affect diclofenac sodium to both sides of membrane.

\section{CONFLICT OF INTEREST}

The authors declare that there is no conflict of interests regarding the publication of this article.

\section{REFERENCES}

1. H. Li and G. Lykotrafitis, Biophys. J., 107, 642 (2014); https://doi.org/10.1016/j.bpj.2014.06.031.

2. E.D.F. De Robertis and E.M.F. De Robertis, Cell and Molecular Biology, Lea and Febiger: USA, edn 8 (1987).

3. M. Ikeda, A. Kihara and Y. Igarashi, Biol. Pharm. Bull., 29, 1542 (2006); https://doi.org/10.1248/bpb.29.1542.

4. P.V. Escribá, J.M. González-Rosb, F.M. Goñi, P.K.J. Kinnunen, L. Vigh, L. Sánchez-Magraner, A.M. Fernández, X. Busquets and I. Horváth, J. Cell. Mol. Med., 12, 829 (2008); https://doi.org/10.1111/j.1582-4934.2008.00281.x.
5. H.P. Fernandes, C.L. Cesar and M.L. Barjas-Castro, Rev. Bras. Hematol. Hemoter, 33, 297 (2011); https://doi.org/10.5581/1516-8484.20110080.

6. P. Atkins and J. Paula, Interações moleculares. In: Atkins Físico-química, Livros Técnicos e Científicos: Rio de Janeiro, edn 7, p. 408 (2004).

7. M.M. Cruz Silva, V.M.C. Madeira, L.M. Almeida and J.B.A. Custódio, Toxicol. In Vitro, 15, 615 (2001);

https://doi.org/10.1016/S0887-2333(01)00079-0.

8. R. Huang, M. Kiss, M. Batonick, M. Weiner and B. Kay, Antibodies, 5, 11 (2016); https://doi.org/10.3390/antib5020011.

9. M. Lucio, J.L.F.C. Lima and S. Reis, Curr. Med. Chem., 17, 1795 (2010); https://doi.org/10.2174/092986710791111233.

10. H. Tsuchiya, Molecules, 20, 18923 (2015); https://doi.org/10.3390/molecules201018923.

11. C. Sousa, C. Nunes, M. Lúcio, H. Ferreira, J.L.F.C. Lima, J. Tavares, A. Cordeiro-da-Silva and S. Reis, J. Pharm. Sci., 97, 3195 (2008); https://doi.org/10.1002/jps.21218.

12. J.G.R. Elferink, Biochem. Pharmacol., 26, 2411 (1977); https://doi.org/10.1016/0006-2952(77)90450-6.

13. S. Ship, Y. Shami, W. Breuer and A. Rothstein, J. Membr. Biol., 33, 311 (1977); https://doi.org/10.1007/BF01869522.

14. H. Passow, Cell Membrane Receptors for Drugs and Hormones: A Multidisciplinary Approach, Ravan Press: New York (1978).

15. M.M. Kamel and Y.M. Syam, Egypt. Pham. J., 12, 95 (2013); https://doi.org/10.4103/1687-4315.124000.

16. M. Reinila, E. MacDonald, N. Salem Jr., M. Linnoila and E.G. Trams, Anal. Biochem., 124, 19 (1982); https://doi.org/10.1016/0003-2697(82)90214-7.

17. O.H. Lowery, N.J. Rosebrough, A.L. Farr and R.J. Randall, J. Biol. Chem., 193, 265 (1951).

18. C.H. Giles, D. Smith and A. Huitson, J. Colloid Interface Sci., 47, 755 (1974); https://doi.org/10.1016/0021-9797(74)90252-5.

19. A.B. Bikhazi, K.M. Bitar, M.M. El-Kasti and E.K. Shaaban, J. Pharm. Sci., 83, 1758 (1994); https://doi.org/10.1002/jps.2600831222.

20. K.J.Laidler, Physical Chemistry with Biological Applications, Benjamin Cummings Publishing Company, Inc.: California, USA (1978).

21. D.Freifelder, Physical Biochemistry: Applications to Biochemistry and Molecular Biology, W.H. Freeman and Company: New York, edn 2 (1982)

22. S. Ishida, Y. Sakiya, T. Ichikawa and Z. Taira, Biol. Pharm. Bull., 16, 293 (1993); https://doi.org/10.1248/bpb.16.293.

23. T. Fujimoto and I. Parmyrd, Front. Cell Dev. Biol., 4, Article 155 (2017); https://doi.org/10.3389/fcell.2016.00155.

24. A.P. Liu and D.A. Fletcher, Biophys. J., 91, 4064 (2006); https://doi.org/10.1529/biophysj.106.090852.

25. M.P. Sheetz and S.J. Singer, Proc Natl. Acad. Sci. USA, 71, 4457 (1974); https://doi.org/10.1073/pnas.71.11.4457.

26. A.B. Hendrich, K. Lichacz, A. Burek and K. Michalak, Cell. Mol. Biol. Lett., 7, 1081 (2002).

27. P.A. Janmey and P.K.J. Kinnunen, Trends Cell Biol., 16, 538 (2006); https://doi.org/10.1016/j.tcb.2006.08.009. 